\title{
Finance and income inequality revisited
}

Yener Altunbaş

The Business School, Bangor University

College Road, Bangor LL57 2DG, UK

Email addresses: $\underline{\text { y.altunbasebangor.ac.uk }}$

and

John Thornton (corresponding author)

Norwich Business School, University of East Anglia, Norwich NR4 $7 \mathrm{TJ}, \mathrm{UK}$

Email address: John.Thornton@uea.ac.uk

and

United States Department of the Treasury, Office of Technical Assistance.1750 Pennsylvania Ave NW

Washington DC 20006, USA. Email address:

John. Thorntondotatreas.us

\section{ABSTRACT}

In a panel of 121 developed and developing economies, financial development promotes income equality in upper-middle income countries and inequality in low- and high-income countries. Finance impacts on income inequality through both the financial institutions and financial markets channels, though the impact of the financial institutions channel is relatively larger.

JEL: D31, D63, F02, O11, O15 
Keywords: Income inequality, Financial development, Financial institutions, Financial markets, Panel regression

Wordcount: 2,249 


\section{Finance and income inequality revisited}

\section{Introduction}

Economists began to examine the link between the development of the financial sector and income inequality in 1990s. For example, Greenwood and Jovanovic (1990) showed how financial and economic development could interact to give rise to an inverted u-shaped relationship between them. ${ }^{1}$ They present a theoretical model in which financial development encourages economic development which, in turn, facilitates necessary investment in financial infrastructure. In their model, economic agents operate the more profitable and riskier of two technologies when they can diversify risk by investing in financial intermediary coalitions. However, the fixed costs associated with the coalitions prevent low-income individuals from participating. On the assumption that poor individuals save less and accumulate wealth more slowly, income differences between members of intermediary coalitions and outsiders will widen, resulting in an increase in income inequality. However, since coalition costs are fixed in the model, all agents eventually join the coalitions, which leads to an eventual reversal in the income inequality trend. Thus, Greenwood

\footnotetext{
1 Greenwood and Jovanovic (1990) had built on the Kuznets' (1955) hypothesis that associated economic development with first an increase and then a decrease in income inequality, giving rise to an inverted u-shaped relationship between the two variables.
} 
and Jovanovic's (1990) model predicts an inverted u-shaped relationship between income inequality and financial sector development, with income inequality first increasing, then decreasing, and eventually stabilizing as more people join financial coalitions.

In contrast, the models of Galor and Zeira (1993) and Banerjee and Newman (1993) suggest that long-run convergence in the income levels of the rich and the poor may not take place in the presence of capital market imperfections and indivisibilities in investment in human or physical capital; rather, income inequality might persist, depending on the initial wealth distribution. Galor and Zeira (1993) construct a two-sector model with bequests between generations, where agents who make an indivisible investment in human capital can work in a skill-intensive sector. However, given capital market imperfections, only individuals with bequests larger than the investment amount or who can borrow will be able to make this investment. This results in income inequality that is perpetuated through bequests to the next generation. In their model, an economy with capital market imperfections and an initial unequal distribution of wealth will maintain the inequality and grow more slowly than a similar economy with a more equitable initial distribution of wealth. Banerjee and Newman (1993) construct a three-sector model in which two of the technologies 
require indivisible investment but where the presence of capital market imperfections mean that only wealthy agents can borrow sufficiently to undertake the indivisible (higher-return) technologies. Both models suggest that countries with larger capital market imperfections (i.e. greater difficulties in accessing funds to finance indivisible investments) should have higher income inequality and that we should observe a negative relationship between financial development and income inequality . Recent reviews of literature (see, e.g., Claessens and Perotti, 2007; Demirgüç-Kunt and Levine, 2009; de Haan and Sturm, 2017) conclude that the empirical evidence on the relationship between finance and income inequality is also ambiguous. This is unfortunate given that the role of finance in income inequality has considerable practical importance (Clarke et al., 2003). First, while a reasonably robust relationship has been established between financial development and economic growth, policymakers are also interested in how the benefits from higher rates of economic growth are distributed.2 Second, given public concerns about income distribution, policymakers should be interested in knowing how policies affect both economic growth and income distribution. Finally, policymakers also likely to be interested

\footnotetext{
2 Beck et al. (2000), Levine (2005) and Levine et al. (2000) are key studies providing empirical evidence on the relationship between financial development and growth.
} 
in whether and in what context finance can be used as an instrument to affect income inequality.

In this paper, we revisit the empirical relationship between finance and income inequality and make several contributions to the empirical literature. First, in contrast to most studies that rely on the ratio to GDP of bank credit or broad money supply as measures of financial development, we make use of the index of financial development produced by the IMF, which captures better the depth, access, and efficiency characteristics of financial development (Svirydzenka, 2016). Second, we shed light on the relative importance of financial institutions vs. financial markets as channels of influence on income inequality. For this, we employ the two major sub-components of the IMF index, which measure separately the contributions to financial development from financial institutions and from financial markets. While there has been considerable research on the relative impact of these two channels on economic growth (e.g., Levine and Servos, 1998; Beck and Levine, 2004; Demirgüç-Kunt and Levine, 2001; Luintel et al., 2008), there has been little research as to their relative impact on income inequality and the research that exists provides conflicting results. For example, Demirgüç-Kunt et al. (2013) find that the importance for economic activity of services provided by securities markets increase relative to those provided by banks as 
economies develop. In contrast, Gimet and Lagoarde-Segot (2011) and Naceur and Zhang (2019) report that the banking sector exerts a stronger impact on income inequality relative to that of financial markets. Third, the mixed results from studies regarding the impact of finance on inequality partly reflects differences in data sources, sample size and estimation methodologies. Thus, we employ large number of countries at different levels of income in our data panel, which allows us to examine the effects of finance on income inequality across country income groups. Finally, we test the robustness of our results to several different estimation methodologies.

\section{Model and data}

We estimate a dynamic panel model that takes the following form:

$$
\operatorname{Gini}_{i t}=\alpha_{i}+F D_{i, t-1}+X_{i, t-1}+\mu_{i t}
$$

The dependent variable, Gini, is the Gini coefficient based on households' income before taxes to proxy for income inequality before redistribution via the tax system. The data is from solt's (2009) Standardized World Income Inequality Database (SWIID) where the standardization of incomes facilitates comparisons across countries. Financial development, FD, is measured as either the IMF's index of: (i) total financial development; (ii) financial 
institutions development; or (iii) financial markets development. The Vector $X$ comprises a number of variables used commonly in estimates of the determinants of income distribution and includes the growth rate of real GDP, the rate of inflation, the ratio of foreign trade (imports plus exports) to GDP, the ratio of government consumption to GDP; an index of representative government, and a dummy variable to control for the impact of economic crisis. In terms of our expectations for the impact of the controls on income distribution: Piketty ( 2014) argues that low GDP growth is associated with greater income inequality; Romer and Romer (1999) argue that inflation depresses the average incomes and incomes of the poor because it adds to economic uncertainty; Winters et al. (2004) argue that theory and empirical evidence suggest that trade liberalization reduces poverty; Meltzer and Richard (1981) show that inequality leads to a demand for redistributive policies that increase the size of government; Acemoglu et al. (2015) make the case that more voter representation will increase redistribution and reduce inequality; and de Haan and Sturm (2017) argue that the poor suffer disproportionately from economic recessions. Our panel comprises annual data for 121 countries for the period 1980-2015 with the data organized into five-year non-overlapping averages to abstract from short-term cyclical developments and because the annual income inequality data in SWIID are imputed for years for which data is not 
available. More explanation of the variables, summary descriptive statistics and the data sources are provided in Table 1.

We initially estimate panel regressions with fixed country and year effects because of the lack of homogeneity in the country sample. However, as the inclusion of fixed effects means that variables with little within-country time variation are not estimated with precision, we also present results from random effects estimates. One problem with such estimates of equation (1) is potential endogeneity. This might result, for example, if low income households were successful in demanding more credit to reduce their consumption disparities with high-income households. We try to address endogeneity concerns in three ways. First, in both sets of estimates we lag all the independent variables by one (five-year) period. Second, we present results in which we have followed the common practice of instrumenting financial development using and legal origin dummies and lagged values of the finance variable (see, e.g., Levine, 2005). ${ }^{3}$ Finally, we report results using the dynamic Generalized Method of Moments (GMM) methodology to obtain consistent estimates of the impact of financial development on income equality (Arellano and Bond,1991; Blundell and Bond, 1998).

\footnotetext{
3 La Porta et al. (1997, 1998) show that the introduction of common or civil law into a country via conquest or colonization affected the legal rules and the development of institutions in those countries.
} 


\section{Results}

Baseline estimates of equation (1) are reported in Table 2 with the results organized into three panels according to the measure of financial development employed. For each measure of financial development and for each methodology, the coefficient on the financial development variable is positive and statistically significant, which is consistent with finance promoting greater income inequality. The coefficients on total financial development (panel A) are broadly similar in size across the different methodologies (0.08-0.10) and are quite substantial in terms of economic impact, with a one standard deviation increase in financial development increasing the Gini coefficient by between 1.55-2.00 percentage points in a 5-year period (where the sample mean for the Gini coefficient is 45.68).4 Of the control variables, growth of real GDP per capita reduces income inequality, but inflation, trade openness, government consumption expenditure, and economic crises appear to promote greater income inequality, and the coefficients on representative government are never statistically significant. The results reported in panels $B$ and C of the table show that the impact of financial development on income inequality runs through both the development of financial

\footnotetext{
44 For example, in the fixed effects estimates of Table 2 (column 1): $1.64=0.083$ (coefficient on financial development) * 19.768 (the standard deviation of total financial development reported in Table 1).
} 
institutions (panel B) and through financial markets (panel C), though the economic impact of financial institution development appears to be relatively larger with a one standard deviation increase in its development raising the Gini coefficient by 1.291.46 percentage points compared to $0.71-1.28$ in the case of financial markets development. This finding is consistent with Gimet and Lagoarde-Segot (2011) and Naceur and Zhang (2016). The impact of the control variables on the Gini coefficient in these estimates is similar to that for total financial development.

In Tables 3-5, we present results for the impact of each measure of financial development according to country groupings classified according to the World Bank's income classification system. Table 3 reports results for total financial development. The results for high-income countries (panel A) and lower income countries (panel C) are in line with those for the full sample of countries, suggesting that more financial development increases income inequality. In these cases, the adverse impact of financial development on income inequality is somewhat larger on high-income countries than it is for lower-income countries, where the size of financial sector is typically significantly smaller. For example, a one standard deviation increase in financial development in highincome countries raises the Gini coefficient by up to 1.95 percentage points compared to up 1.21 percentage points in low- 
income countries. For upper-middle income countries (panel B), however, financial development appears to reduce income inequality. The coefficients on financial development are always negative and statistically significant and indicate that a one standard deviation increase in financial development reduces the Gini coefficient by up to 0.95 percentage points in a five-year period. Of the control variables, the adverse impact of trade openness on the Gini coefficient appears to be limited to highincome countries, and economic crisis and representative government appear to impact the most in upper middle-income countries. Contrary to our expectations, more representative government appears to be consistent with more unequal income distribution

The same general pattern emerges from the estimates that focus on financial institutions development and financial markets development as the measures of financial development, which are reported in Tables 4 and 5, respectively. The coefficients on financial development are statistically significant and are positive for high- and lower-income countries and negative for upper-middle-income countries. That is, financial development impacts income inequality through both the financial institutions and markets channels, promoting greater income inequality in highand lower-income countries and greater equality in upper-middle 
income countries. This is broadly consistent with the Galor and Zeira (1993) and Galor and Moav (2004) view of a negative relationship between finance and income inequality as economic development proceeds. In addition, the impact of finance on income inequality (through both channels) is generally somewhat larger in high-income countries, and the impact of the financial institutions channel is generally consistently larger than that of the financial markets channel.

\section{Conclusion}

We examine the impact of financial development on income distribution in a panel of 121 countries. We find that the impact of finance changes with a country's level of income, promoting income equality in upper-middle income countries and inequality in low- and high-income countries, and that the impact of finance is generally larger in high-income countries. In addition, while finance impacts on inequality through both the financial institutions and financial markets channels, the impact of the financial institutions channel is relatively larger. Our results are robust to different methodologies. 


\section{References}

Acemoglu, D., Naidu, S., Restrepo, P., Robinson, J.A., 2015. Democracy, redistribution, and inequality. In Atkinson, A., Bourguignon, F. (Eds.), Handbook of Income Distribution Vol. 2B.__ Publishing Company and American Elsevier Publishing Company, North-Holland.

Arellano, M., Bond, S., 1991. Some tests of specification for panel data: Monte Carlo evidence and an application to employment equations. The Review of Economic Studies 58, 277-297

Banerjee, A.V., Newman, A.F., 1993. Occupational choice and the process of development. Journal of Political Economy 101, $274-298$.

Beck, T., Levine, R., 2004. Stock markets, banks, and growth: Panel evidence. Journal of Banking and Finance 28, 423-42. Beck, T., Levine, R., Loayza, N., 2000. Finance and the sources of growth. Journal of Financial Economics 50, 261-300. Blundell, R., Bond, S., 1998. Initial conditions and moment restrictions in dynamic panel data models. Journal of Econometrics 87, 115-143.

Claessens, S., Perrotti, E., 2007. Finance and inequality: channels and evidence. Journal of Comparative Economics $35,748-773$ 
Clarke, G., Xu, L. C., Zou, H., 2003. Finance and income inequality: Test of alternative theories. World Bank Policy Research Working Paper 284 .

De Haan, J., Sturm, J-E., 2017. Finance and income inequality: a review and new evidence. European Journal of Political Economy 50, 171-195.

Demirgüç-Kunt, A., Feijen, E., Levine, R., 2013. The evolving importance of banks and securities markets. World Bank Economic Review 27, 476-490.

Demirgüç-Kunt, A., Levine, R., 2009. Finance and inequality: theory and evidence. Annual Review of Financial Economics 1, $287-318$

Demirgüç-Kunt, A., Levine, R., 2001. Financial structures and economic growth: a cross-country comparison of banks, markets and development, Cambridge, MIT Press. Galor, O., Zeira, J., 1993. Income distribution and macroeconomics. Review of Economic Studies 60, 35-52. Gimet, C., Lagoarde-Segot, T., 2011. A closer look at financial development and income distribution. Journal of Banking and Finance 35, 1698-1713.

Greenwood, J., Jovanovic, B., 1990.Financial development, growth, and the distribution of income. Journal of Political Economy 98, 1076-1107. 
Kuznets, S., 1955. Economic growth and income inequality. American Economic Review 45, 1-28.

La Porta, R., Lopez-de-Silanes, F., Shleifer, A., Vishny, R.W., 1997. Legal determinants of external finance. Journal of Finance 52, 1131-1150.

La Porta, R., Lopez-de-Silanes, F., Shleifer, A., Vishny, R.W., 1998. Law and finance. Journal of Political Economy 106, $1113-1155$

Laeven, L., Valencia, F., 2013. Systemic banking crises database. IMF Review 61, 225-270.

Levine, R., 2005. Finance and Growth: Theory and Evidence. In: Aghion, P., Durlauf, D. (Eds.), Handbook of Economic Growth. Elsevier Science, The Netherlands, pp. 866-934.

Levine, R., Loayza, N., Beck, T., 2000. Financial intermediation and growth: Causality and causes. Journal of Monetary Economics $46,31-77$.

Levine, R., Servos, A., 1998. Stock markets, banks, and economic growth. American Economic Review 88, 537-558.

Luintel, K.B., Khan, M., Arestis, P., Theodoridis, K., 2008. Financial structure and economic growth. Journal of Development Economics 86, 181-200. Meltzer, A.H., Richard, S.F., 1981. A rational theory of the size of government. Journal of Political Economy 89, 914-927 
Naceur, S.B., Zhang, R., 2019. Financial development, inequality and poverty: some international evidence. International Review of Economics and Finance 61, 1-16.

Piketty, T., 2014. Capital in the 21st Century. Harvard University Press, Cambridge, Mass

Romer, C.D., Romer, D.H., 1998. Monetary policy and the wellbeing of the poor. NBER Working Paper 6793.

Solt, F, 2009. Standardizing the world income inequality database. Social Science Quarterly 90, 231-242.

Svirydzenka, K., 2016. Introducing a New Broad-based Index of Financial Development IMF Working Paper No. 16/5. Winters, L.A., McCulloch, N., McKay, A., 2004. Trade liberalization and poverty: the evidence so far Journal of Economic Literature 42, 72-115. 
Table 1

Variable description, data sources and summary statistics

\begin{tabular}{|c|c|c|c|c|c|c|c|}
\hline Variable & Description & Source & Mean & $\begin{array}{l}\text { Medi } \\
\text { an }\end{array}$ & $\begin{array}{l}\text { Standar } \\
\text { d } \\
\text { deviati } \\
\text { on }\end{array}$ & $\underset{\mathrm{m}}{\operatorname{Minimu}}$ & Maximum \\
\hline Gini coefficient & $\begin{array}{l}\text { The Gini coefficient measures income } \\
\text { inequality, where } 0 \text { resembles a perfectly equal } \\
\text { outcome and } 100 \text { per cent reflects and extremely } \\
\text { unequal condition. The coefficient is based on } \\
\text { pre-tax, pre-transfer household income. }\end{array}$ & $\begin{array}{l}\text { SWIID, Solt } \\
(2009)\end{array}$ & $\begin{array}{l}45.6 \\
8\end{array}$ & $\begin{array}{l}45.3 \\
7\end{array}$ & 6.919 & 21.76 & 68.38 \\
\hline $\begin{array}{l}\text { Total financial } \\
\text { development } \\
\text { Financial }\end{array}$ & $\begin{array}{l}\text { Financial development reflects the aggregation } \\
\text { of nine indices that assess at different levels } \\
\text { of abstraction how developed financial systems }\end{array}$ & IMF & $\begin{array}{l}28.5 \\
3\end{array}$ & $\begin{array}{l}22.5 \\
6\end{array}$ & 19.768 & 0.01 & 94.84 \\
\hline $\begin{array}{l}\text { institutions } \\
\text { development }\end{array}$ & $\begin{array}{l}\text { are across countries. Six lower level sub- } \\
\text { indices are constructed using a list of }\end{array}$ & & $\begin{array}{l}39.3 \\
5\end{array}$ & $\begin{array}{l}33.2 \\
7\end{array}$ & 20.947 & 0.80 & 97.87 \\
\hline $\begin{array}{l}\text { Financial markets } \\
\text { development }\end{array}$ & $\begin{array}{l}\text { indicators to measure how deep, accessible, and } \\
\text { efficient financial institutions and financial } \\
\text { markets are. These sub-indices are aggregated } \\
\text { into two higher level sub-indices that measure } \\
\text { how developed financial institutions and } \\
\text { financial markets are overall. Finally, these } \\
\text { two sub-indices are aggregated into an overall } \\
\text { measure of financial development-the Financial } \\
\text { Development index (Svirydzenka, 2016) }\end{array}$ & & $\begin{array}{l}18 \cdot 8 \\
1\end{array}$ & $\begin{array}{l}10.3 \\
6\end{array}$ & 21.542 & 0.03 & 93.25 \\
\hline GDP growth & Annual percent change in GDP per capita & WDI & 3.45 & 3.49 & 3.255 & -20.62 & 18.35 \\
\hline Inflation & Annual percent change in consumer prices & WDI & $\begin{array}{l}14 \cdot 5 \\
2\end{array}$ & 7.96 & 19.846 & 0.08 & 91.04 \\
\hline Trade openness & Ratio to GDP of exports plus imports & WDI & $\begin{array}{l}68.7 \\
2\end{array}$ & $\begin{array}{l}61.8 \\
8\end{array}$ & 32.232 & 7.71 & 148.33 \\
\hline $\begin{array}{l}\text { Government } \\
\text { consumption }\end{array}$ & $\begin{array}{l}\text { Ratio to GDP of general government final } \\
\text { consumption expenditure }\end{array}$ & WDI & $\begin{array}{l}15.5 \\
0\end{array}$ & $\begin{array}{l}15 \cdot 0 \\
2\end{array}$ & 5.169 & 3.92 & 29.58 \\
\hline $\begin{array}{l}\text { Representative } \\
\text { government }\end{array}$ & $\begin{array}{l}\text { An index that captures contested and inclusive } \\
\text { popular elections for legislative and executive } \\
\text { office, }\end{array}$ & IDEA & $\begin{array}{l}54 \cdot 4 \\
6\end{array}$ & $\begin{array}{l}59.8 \\
7\end{array}$ & 25.321 & 0.00 & 94.67 \\
\hline Economic crisis & $\begin{array}{l}\text { Dummy variable ranging between } 0 \text { to } 3 \text { for each } \\
\text { year depending upon whether a country } \\
\text { experienced no crisis or one or more of a } \\
\text { systemic banking crisis, a currency crisis, or } \\
\text { a sovereign debt crisis, }\end{array}$ & $\begin{array}{l}\text { Laeven and } \\
\text { Valencia } \\
(2013)\end{array}$ & 0.39 & 0.00 & 0.729 & 0.00 & 4.00 \\
\hline
\end{tabular}

Bank's World Development Indicators database; IDEA is the International Institute for Democracy and Electoral Assistance. 
For the purpose of calculating the economic impact of financial development across country groups, the relevant standard deviations for the different measures of financial development are: (i) high-income: total financial development, 20.696; financial institutions development, 17.559; financial markets development, 25.327; (ii) upper-middle income: total

financial development, 12.573; financial institutions development, 13.133; financial markets development, 15.754; and (iii)

low- and lower-middle income: total financial development, 7.869; financial institutions development, 8.569; financial markets development, 10.832 . 
Table 2

Financial development and income inequality: dependent variable Gini coefficient

\begin{tabular}{|c|c|c|c|c|}
\hline & $\begin{array}{c}\text { Fixed } \\
\text { effects }\end{array}$ & $\begin{array}{l}\text { Random } \\
\text { effects }\end{array}$ & IV & System-GMM \\
\hline \multicolumn{5}{|l|}{ A Total financial development } \\
\hline Lagged Gini & & & & $\begin{array}{l}0.1071 * \star \star \\
(0.0134)\end{array}$ \\
\hline Financial development & $\begin{array}{l}0.0828 * \star \star \\
(0.0107)\end{array}$ & $\begin{array}{l}0.0785 * \star \star \\
(0.0104)\end{array}$ & $\begin{array}{l}0.0852 * \star \star \\
(0.0124)\end{array}$ & $\begin{array}{l}0.1013 * \star \star \\
(0.0187)\end{array}$ \\
\hline Growth of GDP per capita & $\begin{array}{l}-0.0666 * \star \\
(0.0296)\end{array}$ & $\begin{array}{l}-0.0641 * \star \\
(0.0297)\end{array}$ & $\begin{array}{l}-0.0619 * \star \\
(0.0300)\end{array}$ & $\begin{array}{l}-0.0352 \\
(0.0280)\end{array}$ \\
\hline Inflation & $\begin{array}{l}0.0130 * * \\
(0.0061)\end{array}$ & $\begin{array}{l}0.0126 * \star \\
(0.0061)\end{array}$ & $\begin{array}{l}0.0135 * \star \\
(0.0062)\end{array}$ & $\begin{array}{l}-0.0287 \star \star \star \\
(0.0085)\end{array}$ \\
\hline Trade openness & $\begin{array}{l}0.0156 * \star \\
(0.0069)\end{array}$ & $\begin{array}{l}0.0139 * \star \\
(0.0065)\end{array}$ & $\begin{array}{c}0.0125 \star \\
(0.0066)\end{array}$ & $\begin{array}{l}-0.0044 \\
(0.0030)\end{array}$ \\
\hline Government consumption & $\begin{array}{c}0.0654 \star \\
(0.0354)\end{array}$ & $\begin{array}{l}0.0699 * \star \\
(0.0344)\end{array}$ & $\begin{array}{l}0.0693 * * \\
(0.0346)\end{array}$ & $\begin{array}{c}0.0547 \star \\
(0.0332)\end{array}$ \\
\hline Representative government & $\begin{array}{l}-0.0003 \\
(0.0069)\end{array}$ & $\begin{array}{l}-0.0005 \\
(0.0067)\end{array}$ & $\begin{array}{l}-0.0010 \\
(0.0068)\end{array}$ & $\begin{array}{l}-0.0273 * \star \star \\
(0.0086)\end{array}$ \\
\hline Crisis & $\begin{array}{l}0.3508 * \star \star \\
(0.1269)\end{array}$ & $\begin{array}{l}0.3367 * \star \star \\
(0.1274)\end{array}$ & $\begin{array}{l}0.3293 * \star \star \\
(0.1286)\end{array}$ & $\begin{array}{c}0.1240 \\
(0.1205)\end{array}$ \\
\hline $\begin{array}{l}\mathrm{R}^{2} \\
\text { Arellano-Bond AR1/AR2 (p-values) } \\
\text { Sargan test (p-value) }\end{array}$ & 0.168 & 0.168 & 0.167 & $\begin{array}{l}0.009 / 0.876 \\
0.502\end{array}$ \\
\hline $\begin{array}{l}\text { B. Financial Institutions } \\
\text { development }\end{array}$ & & & & \\
\hline Lagged Gini & & & & $\begin{array}{l}0.3360 * \star \star \\
(0.0934)\end{array}$ \\
\hline Financial institutions development & $\begin{array}{l}0.0697 \star \star \star \\
(0.0140)\end{array}$ & $\begin{array}{l}0.0618 * \star \star \star \\
(0.0130)\end{array}$ & $\begin{array}{l}0.0681 * \star \star \\
(0.0169)\end{array}$ & $\begin{array}{l}0.0645 \star \\
(0.0372)\end{array}$ \\
\hline Growth of GDP per capita & $\begin{array}{l}-0.0726 * \star \\
(0.0305)\end{array}$ & $\begin{array}{l}-0.0700 * \star \\
(0.0306)\end{array}$ & $\begin{array}{l}-0.0665 * \star \\
(0.0315)\end{array}$ & $\begin{array}{l}-0.0462 * \star \\
(0.0180)\end{array}$ \\
\hline Inflation & $\begin{array}{l}0.0172 * \star \\
(0.0068)\end{array}$ & $\begin{array}{l}0.0154 * \star \\
(0.0067)\end{array}$ & $\begin{array}{l}0.0170 * * \\
(0.0071)\end{array}$ & $\begin{array}{c}0.0015 \\
(0.0032)\end{array}$ \\
\hline Trade openness & $\begin{array}{l}0.0243 * \star \star \\
(0.0069)\end{array}$ & $\begin{array}{l}0.0214 * \star \star \\
(0.0065)\end{array}$ & $\begin{array}{l}0.0203 * \star \star \\
(0.0067)\end{array}$ & $\begin{array}{c}0.0073 \\
(0.0056)\end{array}$ \\
\hline Government consumption & $\begin{array}{l}0.0700 * \\
(0.0164)\end{array}$ & $\begin{array}{l}0.0709 * \star \\
(0.0354)\end{array}$ & $\begin{array}{l}0.0722 * \star \\
(0.0359)\end{array}$ & $\begin{array}{l}0.1373 * \star \star \\
(0.0185)\end{array}$ \\
\hline Representative government & $\begin{array}{c}0.0048 \\
(0.0071)\end{array}$ & $\begin{array}{c}0.0038 \\
(0.0069)\end{array}$ & $\begin{array}{c}0.0031 \\
(0.0071)\end{array}$ & $\begin{array}{c}0.0046 \\
(0.0144)\end{array}$ \\
\hline Crisis & $\begin{array}{l}0.3624 * \star \star \\
(0.1308)\end{array}$ & $\begin{array}{l}0.3459 * \star \star \\
(0.1313)\end{array}$ & $\begin{array}{l}0.3460 * \star \\
(0.1353)\end{array}$ & $\begin{array}{c}0.0288 \\
(0.1563)\end{array}$ \\
\hline $\mathrm{R}^{2}$ & 0.120 & 0.120 & 0.117 & \\
\hline $\begin{array}{l}\text { Arellano-Bond AR1/AR2 (p-values) } \\
\text { Sargan test (p-value) }\end{array}$ & & & & $\begin{array}{l}0.019 / 0.563 \\
0.200\end{array}$ \\
\hline $\begin{array}{l}\text { C. Financial markets development } \\
\text { Lagged Gini }\end{array}$ & & & & $\begin{array}{l}0.2870 * \star \\
(0.1168)\end{array}$ \\
\hline Financial markets development & $\begin{array}{l}0.0583 * \star * \\
(0.0075)\end{array}$ & $\begin{array}{l}0.0573 * \star * \\
(0.0074)\end{array}$ & $\begin{array}{l}0.0593 * \star \star \\
(0.0074)\end{array}$ & $\begin{array}{l}0.0329 * \star \star \\
(0.0074)\end{array}$ \\
\hline Growth of GDP per capita & $\begin{array}{l}-0.0687 \star \star \\
(0.0299)\end{array}$ & $\begin{array}{l}-0.0637 \star \star \\
(0.0300)\end{array}$ & $\begin{array}{l}-0.0571 \star \\
(0.0302)\end{array}$ & $\begin{array}{c}-0.0016 \\
(0.0158)\end{array}$ \\
\hline Inflation & $\begin{array}{c}0.0066 \\
(0.0061)\end{array}$ & $\begin{array}{l}-0.0070 \\
(0.0060)\end{array}$ & $\begin{array}{c}0.0084 \\
(0.0058)\end{array}$ & $\begin{array}{l}0.0079 * \star \\
(0.0039)\end{array}$ \\
\hline Trade openness & $\begin{array}{l}0.0162 * \star \\
(0.0070)\end{array}$ & $\begin{array}{l}0.0143 * * \\
(0.0065)\end{array}$ & $\begin{array}{c}0.0129 \star \\
(0.0066)\end{array}$ & $\begin{array}{c}0.0081 \\
(0.0059)\end{array}$ \\
\hline Government consumption & $\begin{array}{l}0.0700 * \\
(0.0367)\end{array}$ & $\begin{array}{l}0.0827 \star \star \\
(0.0356)\end{array}$ & $\begin{array}{l}0.0685 * \star \\
(0.0346)\end{array}$ & $\begin{array}{l}0.1619 * \star \star \\
(0.0226)\end{array}$ \\
\hline Representative government & $\begin{array}{l}-0.0038 \\
(0.0071)\end{array}$ & $\begin{array}{l}-0.0026 \\
(0.0070)\end{array}$ & $\begin{array}{c}0.0116 \\
(0.0076)\end{array}$ & $\begin{array}{c}0.0266 \\
(0.0187)\end{array}$ \\
\hline Crisis & $\begin{array}{l}0.3658 * \star \star \\
(0.1292)\end{array}$ & $\begin{array}{l}0.3571 * \star \star \\
(0.1296)\end{array}$ & $\begin{array}{l}0.4366 * \star \star \\
(0.1249)\end{array}$ & $\begin{array}{c}0.0776 \\
(0.1625)\end{array}$ \\
\hline $\mathrm{R}^{2}$ & 0.173 & 0.173 & 0.173 & \\
\hline $\begin{array}{l}\text { Arellano-Bond AR1/AR2 (p-values) } \\
\text { Sargan test (p-value) }\end{array}$ & & & & $\begin{array}{l}0.030 / 0.304 \\
0.128\end{array}$ \\
\hline
\end{tabular}


710 observations in each panel. IV=instrumental variables. ***, ** and * indicate statistical significance at the 1\%, 5\% and 10\% levels, respectively. 
Table 3

Total financial development and income inequality by country income classification: dependent variable Gini coefficient

\begin{tabular}{|c|c|c|c|c|}
\hline & Fixed effects & Random effects & IV & GMM \\
\hline \multicolumn{5}{|l|}{ A. High-income countries } \\
\hline Lagged Gini & & & & $\begin{array}{l}0.7372 * \star \star \\
(0.0288)\end{array}$ \\
\hline Total financial development & $\begin{array}{l}0.0942 * * * \\
(0.0170)\end{array}$ & $\begin{array}{l}0.0876 * * * \\
(0.0113)\end{array}$ & $\begin{array}{l}0.0896 * * * \\
(0.0134)\end{array}$ & $\begin{array}{l}0.0138 * \star \star \\
(0.0053)\end{array}$ \\
\hline Growth of GDP per capita & $\begin{array}{l}-0.1214 \\
(0.0778)\end{array}$ & $\begin{array}{c}-0.1334^{\star} \\
(0.0746)\end{array}$ & $\begin{array}{c}-0.1344 \star \\
(0.0734)\end{array}$ & $\begin{array}{c}-0.04696 \\
(0.0459)\end{array}$ \\
\hline Inflation & $\begin{array}{c}0.0045 \\
(0.0101)\end{array}$ & $\begin{array}{c}0.0055 \\
(0.0103)\end{array}$ & $\begin{array}{c}0.0062 \\
(0.0105)\end{array}$ & $\begin{array}{l}0.0175 * \star \star \\
(0.0063)\end{array}$ \\
\hline Trade openness & $\begin{array}{l}0.0347 * \star * \\
(0.0092)\end{array}$ & $\begin{array}{l}0.0291 * \star \star \\
(0.0085)\end{array}$ & $\begin{array}{l}0.0282 * * * \\
(0.0086)\end{array}$ & $\begin{array}{l}0.0090 \star \star \\
(0.0056)\end{array}$ \\
\hline Government spending & $\begin{array}{c}0.1486 * \\
(0.0833)\end{array}$ & $\begin{array}{l}0.1955 * \star \\
(0.0779)\end{array}$ & $\begin{array}{l}0.1974 * \star \\
(0.0790)\end{array}$ & $\begin{array}{l}0.1373 * \star \star \\
(0.0038)\end{array}$ \\
\hline Representative government & $\begin{array}{c}0.0035 \\
(0.0116)\end{array}$ & $\begin{array}{c}0.0052 \\
(0.0118)\end{array}$ & $\begin{array}{c}0.0055 \\
(0.0116)\end{array}$ & $\begin{array}{c}0.0214^{\star} \\
(0.0608)\end{array}$ \\
\hline Crisis & $\begin{array}{c}0.3748 \\
(0.2406)\end{array}$ & $\begin{array}{c}0.3675 \\
(0.2311)\end{array}$ & $\begin{array}{c}0.3647 \\
(0.2332)\end{array}$ & $\begin{array}{l}1.3136 * \star \star \\
(0.1563)\end{array}$ \\
\hline $\begin{array}{l}\mathrm{R}^{2} \\
\text { Arellano-Bond AR1/AR2 (p-values) } \\
\text { Sargan test (p-value) }\end{array}$ & 0.093 & 0.095 & 0.095 & $\begin{array}{l}0.036 / 0.604 \\
0.138\end{array}$ \\
\hline $\begin{array}{l}\text { B. Upper middle-income countries } \\
\text { Lagged Gini }\end{array}$ & & & & $\begin{array}{l}0.7095 * \star \star \\
(0.1084)\end{array}$ \\
\hline Total financial development & $\begin{array}{l}-0.0763 * \star * \\
(0.0281)\end{array}$ & $\begin{array}{l}-0.0623 * \star \\
(0.0283)\end{array}$ & $\begin{array}{l}-0.0634 * \star \\
(0.0282)\end{array}$ & $\begin{array}{l}-0.0574 * * \\
(0.0231)\end{array}$ \\
\hline Growth of GDP per capita & $\begin{array}{l}-0.0286 \\
(0.0352)\end{array}$ & $\begin{array}{l}-0.0331 \\
(0.0366)\end{array}$ & $\begin{array}{l}-0.0332 \\
(0.0364)\end{array}$ & $\begin{array}{l}-0.0419 \\
(0.0285)\end{array}$ \\
\hline Inflation & $\begin{array}{l}0.0191 * \star \\
(0.0095)\end{array}$ & $\begin{array}{l}0.0192 * \star \\
(0.0098)\end{array}$ & $\begin{array}{l}0.0193 * \star \\
(0.0097)\end{array}$ & $\begin{array}{l}0.0194 * \star \\
(0.0080)\end{array}$ \\
\hline Trade openness & $\begin{array}{c}0.0171 \\
(0.0150)\end{array}$ & $\begin{array}{r}0.0062 \\
(0.0144)\end{array}$ & $\begin{array}{c}0.0067 \\
(0.0143)\end{array}$ & $\begin{array}{c}0.0058 \\
(0.0125)\end{array}$ \\
\hline Government spending & $\begin{array}{l}0.1535 * \star \\
(0.0682)\end{array}$ & $\begin{array}{l}0.1648 * \star \\
(0.0690)\end{array}$ & $\begin{array}{l}0.1641 * \star \\
(0.0687)\end{array}$ & $\begin{array}{l}0.1641 * \star \\
(0.0687)\end{array}$ \\
\hline Representative government & $\begin{array}{l}0.0372 * \star \star \\
(0.0125)\end{array}$ & $\begin{array}{l}0.0362 * \star * \\
(0.0127)\end{array}$ & $\begin{array}{l}0.0325 * * * \\
(0.0126)\end{array}$ & $\begin{array}{c}0.0075 \\
(0.0087)\end{array}$ \\
\hline Crisis & $\begin{array}{c}0.3469 * \\
(0.1983)\end{array}$ & $\begin{array}{c}0.3610 * \\
(0.2044)\end{array}$ & $\begin{array}{c}0.3620 * \\
(0.2033)\end{array}$ & $\begin{array}{l}1.5529 \star \\
(0.7933)\end{array}$ \\
\hline $\begin{array}{l}\mathrm{R}^{2} \\
\text { Arellano-Bond AR1/AR2 (p-values) } \\
\text { Sargan test (p-value) }\end{array}$ & 0.130 & 0.136 & 0.134 & $\begin{array}{l}0.020 / 0.857 \\
0.433\end{array}$ \\
\hline $\begin{array}{l}\text { C. Lower- and lower-middle- } \\
\text { income countries } \\
\text { Lagged Gini }\end{array}$ & & & & $\begin{array}{l}0.000 \\
(0.000)\end{array}$ \\
\hline Total financial development & $\begin{array}{l}0.1533 * \star \star \\
(0.0490)\end{array}$ & $\begin{array}{l}0.1393 * \star \star \\
(0.0465)\end{array}$ & $\begin{array}{l}0.1443 * \star \star \\
(0.0519)\end{array}$ & $\begin{array}{l}0.0841^{\star \star} \\
(0.0400)\end{array}$ \\
\hline Growth of GDP per capita & $\begin{array}{l}-0.0811 \star \star \\
(0.0361)\end{array}$ & $\begin{array}{l}-0.0760 * \star \\
(0.0365)\end{array}$ & $\begin{array}{c}-0.0734 \star \\
(0.0382)\end{array}$ & $\begin{array}{c}-0.1132 \star \\
(0.0641)\end{array}$ \\
\hline Inflation & $\begin{array}{c}0.0034 \\
(0.0181)\end{array}$ & $\begin{array}{c}0.0042 \\
(0.0183)\end{array}$ & $\begin{array}{c}0.0086 \\
(0.0175)\end{array}$ & $\begin{array}{l}-0.0006 \\
(0.0167)\end{array}$ \\
\hline Trade openness & $\begin{array}{l}-0.0013 \\
(0.0096)\end{array}$ & $\begin{array}{l}-0.0028 \\
(0.0095)\end{array}$ & $\begin{array}{l}-0.0070 \\
(0.0140)\end{array}$ & $\begin{array}{c}0.0068 \\
(0.0269)\end{array}$ \\
\hline Government spending & $\begin{array}{c}0.0381 \\
(0.0554)\end{array}$ & $\begin{array}{c}0.0395 \\
(0.0551)\end{array}$ & $\begin{array}{r}0.0321 \\
(0.0539)\end{array}$ & $\begin{array}{c}0.0312 \\
(0.0985)\end{array}$ \\
\hline Representative government & $\begin{array}{c}0.0087 \\
(0.0110)\end{array}$ & $\begin{array}{c}0.0087 \\
(0.0109)\end{array}$ & $\begin{array}{c}0.0114 \\
(0.0100)\end{array}$ & $\begin{array}{c}0.0288 * \\
(0.0153)\end{array}$ \\
\hline Crisis & $\begin{array}{c}0.3598 * \\
(0.2073)\end{array}$ & $\begin{array}{c}0.3470 * \\
(0.2076)\end{array}$ & $\begin{array}{l}0.4372 \star \star \\
(0.2163)\end{array}$ & $\begin{array}{l}0.4091 * \star \\
(0.1788)\end{array}$ \\
\hline $\begin{array}{l}\mathrm{R}^{2} \\
\text { Arellano-Bond AR1/AR2 (p-values) } \\
\text { Sargan test (p-value) }\end{array}$ & 0.101 & 0.091 & 0.074 & $\begin{array}{l}0.042 / 0.360 \\
0.829\end{array}$ \\
\hline
\end{tabular}


Notes. Observations: panel $\mathrm{A}=234$, panel $\mathrm{B}=194 .$, panel $\mathrm{C}=-282$ obs. . IV=instrumental variables. GMM estimates are system. $* * *, * *$ and ${ }^{*}$ indicate statistical significance at the $1 \%$, 5\% and $10 \%$ levels, respectively. 
Table 4

Financial institutions development and income inequality by country income classification: dependent variable Gini coefficient

\begin{tabular}{|c|c|c|c|c|}
\hline & Fixed effects & Random effects & IV & GMM \\
\hline \multicolumn{5}{|l|}{ A. High-income countries } \\
\hline Lagged Gini & & & & $\begin{array}{l}0.3360 * * * \\
(0.0934)\end{array}$ \\
\hline $\begin{array}{l}\text { Financial institutions } \\
\text { development }\end{array}$ & $\begin{array}{l}0.1085 * * \star \\
(0.0170)\end{array}$ & $\begin{array}{l}0.0618 * \star \star \\
(0.0130)\end{array}$ & $\begin{array}{l}0.0681 * \star \star \\
(0.0169)\end{array}$ & $\begin{array}{l}0.0645 * \\
(0.0372)\end{array}$ \\
\hline Growth of GDP per capita & $\begin{array}{l}-0.0891 \\
(0.0778)\end{array}$ & $\begin{array}{l}-0.0700 * \star \\
(0.0306)\end{array}$ & $\begin{array}{l}-0.0665 * \star \\
(0.0315)\end{array}$ & $\begin{array}{l}-0.0462 \star \star \\
(0.0180)\end{array}$ \\
\hline Inflation & $\begin{array}{c}0.0136 \\
(0.0114)\end{array}$ & $\begin{array}{l}0.0154 * \star \\
(0.0067)\end{array}$ & $\begin{array}{l}0.0170 * \star \\
(0.0071)\end{array}$ & $\begin{array}{c}0.0015 \\
(0.0032)\end{array}$ \\
\hline Trade openness & $\begin{array}{l}0.0482 * \star \star \\
(0.0088)\end{array}$ & $\begin{array}{l}0.0214 * \star \star \\
(0.0065)\end{array}$ & $\begin{array}{l}0.0203 * \star \star \\
(0.0067)\end{array}$ & $\begin{array}{c}0.0073 \\
(0.0056)\end{array}$ \\
\hline Government spending & $\begin{array}{l}0.2585 * * * \\
(0.0848)\end{array}$ & $\begin{array}{l}0.0709 * \star \\
(0.0354)\end{array}$ & $\begin{array}{l}0.0722 * \star \\
(0.0359)\end{array}$ & $\begin{array}{l}0.1373 * \star \star \\
(0.0185)\end{array}$ \\
\hline Representative government & $\begin{array}{c}0.0111 \\
(0.0141)\end{array}$ & $\begin{array}{c}0.0038 \\
(0.0069)\end{array}$ & $\begin{array}{c}0.0031 \\
(0.0071)\end{array}$ & $\begin{array}{c}0.0046 \\
(0.0144)\end{array}$ \\
\hline Crisis & $\begin{array}{c}0.3478 \\
(0.2406)\end{array}$ & $\begin{array}{l}0.3459 \star \star \star \\
(0.1313)\end{array}$ & $\begin{array}{l}0.3460 * \star \\
(0.1353)\end{array}$ & $\begin{array}{c}0.0288 \\
(0.1563)\end{array}$ \\
\hline $\begin{array}{l}\mathrm{R}^{2} \\
\text { Arellano-Bond AR1/AR2 (p-values) } \\
\text { Sargan test (p-value) }\end{array}$ & 0.120 & 0.120 & 0.117 & $\begin{array}{l}0.019 / 0.563 \\
0.200\end{array}$ \\
\hline $\begin{array}{l}\text { B. Upper middle-income countries } \\
\text { Lagged Gini }\end{array}$ & & & & $\begin{array}{l}0.5010 * * \\
(0.2005)\end{array}$ \\
\hline $\begin{array}{l}\text { Financial institutions } \\
\text { development }\end{array}$ & $\begin{array}{l}-0.0598 * * \\
(0.0260)\end{array}$ & $\begin{array}{l}-0.0502 \star \\
(0.0260)\end{array}$ & $\begin{array}{l}-0.0524 * \star \\
(0.0259)\end{array}$ & $\begin{array}{l}-0.0773 * \star \\
(0.0390)\end{array}$ \\
\hline Growth of GDP per capita & $\begin{array}{l}-0.0430 \\
(0.0371)\end{array}$ & $\begin{array}{l}-0.0407 \\
(0.0376)\end{array}$ & $\begin{array}{l}00.0535 * \star \\
(0.0234)\end{array}$ & $\begin{array}{l}-0.0580 * \\
(0.0334)\end{array}$ \\
\hline Inflation & $\begin{array}{c}0.0144 \\
(0.0104)\end{array}$ & $\begin{array}{c}0.0149 \\
(0.0105)\end{array}$ & $\begin{array}{c}0.0157 \\
(0.0110)\end{array}$ & $\begin{array}{c}0.0110 \\
(0.0126)\end{array}$ \\
\hline Trade openness & $\begin{array}{c}0.0066 \\
(0.0091)\end{array}$ & $\begin{array}{c}0.0065 \\
(0.0093)\end{array}$ & $\begin{array}{l}0.0106 * \star \\
(0.0050)\end{array}$ & $\begin{array}{c}0.0160 \\
(0.0136)\end{array}$ \\
\hline Government spending & $\begin{array}{l}0.1469 * \\
(0.0692)\end{array}$ & $\begin{array}{l}0.1593 * \star \\
(0.0691)\end{array}$ & $\begin{array}{l}0.1460 * \star \\
(0.0721)\end{array}$ & $\begin{array}{l}0.3624 * \star \\
(0.1424)\end{array}$ \\
\hline Representative government & $\begin{array}{l}0.0320 * \star \star \\
(0.0124)\end{array}$ & $\begin{array}{l}0.0326 * \star \star \\
(0.0124)\end{array}$ & $\begin{array}{l}0.0297 * \star \\
(0.0144)\end{array}$ & $\begin{array}{l}0.00357 \star \\
(0.0189)\end{array}$ \\
\hline Crisis & $\begin{array}{l}0.4011^{*} \\
(0.1794)\end{array}$ & $\begin{array}{l}0.3896 * \\
(0.1998)\end{array}$ & $\begin{array}{l}0.3906 * \star \\
(0.1552)\end{array}$ & $\begin{array}{l}1.3451 * \star \star \\
(0.4902)\end{array}$ \\
\hline $\begin{array}{l}\mathrm{R}^{2} \\
\text { Arellano-Bond AR1/AR2 (p-values) } \\
\text { Sargan test (p-value) }\end{array}$ & 0.126 & 0.123 & 0.131 & $\begin{array}{l}0.039 / 0.842 \\
0.307\end{array}$ \\
\hline $\begin{array}{l}\text { C. Lower- and lower-middle- } \\
\text { income countries } \\
\text { Lagged Gini }\end{array}$ & & & & $\begin{array}{l}0.4744 * \star \star \\
(0.0826)\end{array}$ \\
\hline $\begin{array}{l}\text { Financial institutions } \\
\text { development }\end{array}$ & $\begin{array}{l}0.0985 * * * \\
(0.0430)\end{array}$ & $\begin{array}{l}0.0945 * \star \\
(0.0405)\end{array}$ & $\begin{array}{l}0.1454 * \star \\
(0.0629)\end{array}$ & $\begin{array}{l}0.0492 * \star \star \\
(0.0187)\end{array}$ \\
\hline Growth of GDP per capita & $\begin{array}{l}-0.0866 * \star \\
(0.0353)\end{array}$ & $\begin{array}{l}-0.0842 * \star \\
(0.0367)\end{array}$ & $\begin{array}{l}-0.1057 * \star \\
(0.0524)\end{array}$ & $\begin{array}{l}-0.605 \\
(0.0430)\end{array}$ \\
\hline Inflation & $\begin{array}{c}0.0153 \\
(0.0169)\end{array}$ & $\begin{array}{c}0.0152 \\
(0.0170)\end{array}$ & $\begin{array}{l}0.0289 * \star \\
(0.0139)\end{array}$ & $\begin{array}{c}0.0119 \\
(0.0163)\end{array}$ \\
\hline Trade openness & $\begin{array}{c}0.0002 \\
(0.0061)\end{array}$ & $\begin{array}{c}0.0001 \\
(0.0061)\end{array}$ & $\begin{array}{c}0.0055 \\
(0.0101)\end{array}$ & $\begin{array}{c}0.0110 \\
(0.0149)\end{array}$ \\
\hline Government spending & $\begin{array}{l}0.0999 * \\
(0.0564)\end{array}$ & $\begin{array}{c}0.0976 * \\
(0.0571)\end{array}$ & $\begin{array}{c}0.0909 * \\
(0.0519)\end{array}$ & $\begin{array}{l}0.0603 * \star \\
(0.0272)\end{array}$ \\
\hline Representative government & $\begin{array}{c}0.0018 \\
(0.0085)\end{array}$ & $\begin{array}{c}0.0022 \\
(0.0085)\end{array}$ & $\begin{array}{c}0.0059 \\
(0.0121)\end{array}$ & $\begin{array}{c}0.0214 * \\
(0.0111)\end{array}$ \\
\hline Crisis & $\begin{array}{c}0.3157 \\
(0.2743)\end{array}$ & $\begin{array}{c}0.3018 \\
(0.2729)\end{array}$ & $\begin{array}{c}0.2663 \\
(0.4617)\end{array}$ & $\begin{array}{l}1.7730 * \star \star \\
(0.5371)\end{array}$ \\
\hline $\begin{array}{l}\mathrm{R}^{2} \\
\text { Arellano-Bond AR1/AR2 (p-values) } \\
\text { Sargan test (p-value) }\end{array}$ & 0.116 & 0.106 & 0.061 & $\begin{array}{l}0.029 / 0.447 \\
0.523\end{array}$ \\
\hline
\end{tabular}


Observations: panel A=234, panel $\mathrm{B}=194 .$, panel $\mathrm{C}=280$ obs. . IV=instrumental variables. GMM

estimates are system. $* * *, * \star$ and $*$ indicate statistical significance at the $1 \%$, 5\% and $10 \%$ levels, respectively. 
Table 5

Financial markets development and income inequality by country income classification: dependent variable Gini coefficient

\begin{tabular}{|c|c|c|c|c|}
\hline & Fixed effects & $\begin{array}{l}\text { Random } \\
\text { effects }\end{array}$ & IV & GMM \\
\hline \multicolumn{5}{|l|}{ A. High-income countries } \\
\hline Lagged Gini & & & & $\begin{array}{l}0.7956 * \star \star \\
(0.0614)\end{array}$ \\
\hline Financial markets development & $\begin{array}{l}0.0625 * * * \\
(0.0076)\end{array}$ & $\begin{array}{l}0.0599 * * * \\
(0.0074)\end{array}$ & $\begin{array}{l}0.0593 * * * \\
(0.0074)\end{array}$ & $\begin{array}{c}0.0377^{\star} \\
(0.0204)\end{array}$ \\
\hline Growth of GDP per capita & $\begin{array}{l}-0.1464 * \star \\
(0.0699)\end{array}$ & $\begin{array}{l}-0.1640 * \star \\
(0.0712)\end{array}$ & $\begin{array}{l}-0.0571 \star \\
(0.0302)\end{array}$ & $\begin{array}{l}-0.0231 \\
(0.0687)\end{array}$ \\
\hline Inflation & $\begin{array}{l}0.0121 \text { ** } \\
(0.0062)\end{array}$ & $\begin{array}{c}0.0117 * \\
(0.0063)\end{array}$ & $\begin{array}{c}0.0084 \\
(0.0058)\end{array}$ & $\begin{array}{l}-0.0038 \\
(0.0071)\end{array}$ \\
\hline Trade openness & $\begin{array}{l}0.0338 * * \star \\
(0.0092)\end{array}$ & $\begin{array}{l}0.0276^{\star \star \star} \\
(0.0084)\end{array}$ & $\begin{array}{l}0.0129 * \\
(0.0066)\end{array}$ & $\begin{array}{c}0.0288^{\star} \\
(0.0166)\end{array}$ \\
\hline Government spending & $\begin{array}{c}0.0869 \\
(0.0785)\end{array}$ & $\begin{array}{l}0.1475^{*} * \\
(0.0728)\end{array}$ & $\begin{array}{l}0.0685^{* *} \\
(0.0346)\end{array}$ & $\begin{array}{l}0.1452 * \star * \\
(0.0320)\end{array}$ \\
\hline Representative government & $\begin{array}{l}-0.0047 \\
(0.0162)\end{array}$ & $\begin{array}{l}-0.0040 \\
(0.0166)\end{array}$ & $\begin{array}{c}0.0116 \\
(0.0076)\end{array}$ & $\begin{array}{l}0.0653 * \star \\
(0.0299)\end{array}$ \\
\hline Crisis & $\begin{array}{c}0.2978 \\
(0.2174)\end{array}$ & $\begin{array}{c}0.3300 \\
(0.2233)\end{array}$ & $\begin{array}{l}0.4366^{* * *} \\
(0.1249)\end{array}$ & $\begin{array}{l}1.8286^{* \star *} \\
(0.2161)\end{array}$ \\
\hline $\begin{array}{l}\mathrm{R}^{2} \\
\text { Arellano-Bond AR1/AR2 ( } \mathrm{p}- \\
\text { values) } \\
\text { Sargan test (p-value) } \\
\text { B. Upper middle-income } \\
\text { countries }\end{array}$ & 0.095 & 0.091 & 0.092 & $\begin{array}{l}0.039 / 0.899 \\
0.689\end{array}$ \\
\hline Lagged Gini & & & & $\begin{array}{l}0.8421 * \star \star \\
(0.0818)\end{array}$ \\
\hline Financial markets development & $\begin{array}{l}-0.0614 * * * \\
(0.0231)\end{array}$ & $\begin{array}{l}-0.0491^{\star *} \\
(0.0230)\end{array}$ & $\begin{array}{l}-0.0486^{* *} \\
(0.0225)\end{array}$ & $\begin{array}{l}-0.0401^{\star \star} \\
(0.0172)\end{array}$ \\
\hline Growth of GDP per capita & $\begin{array}{l}-0.0249 \\
(0.0352)\end{array}$ & $\begin{array}{l}-0.0268 \\
\star 0.0366)\end{array}$ & $\begin{array}{l}-0.0362 \\
(0.0358)\end{array}$ & $\begin{array}{l}-0.0250 \\
(0.0182)\end{array}$ \\
\hline Inflation & $\begin{array}{l}0.0252 * \star \star \\
(0.0093)\end{array}$ & $\begin{array}{l}0.0238^{*} * \\
(0.0096)\end{array}$ & $\begin{array}{l}0.0257 * \star * \\
(0.0094)\end{array}$ & $\begin{array}{l}0.0465 * * * \\
(0.0165)\end{array}$ \\
\hline Trade openness & $\begin{array}{c}0.0164 \\
(0.0143)\end{array}$ & $\begin{array}{c}0.0072 \\
(0.0140)\end{array}$ & $\begin{array}{c}0.0105 \\
(0.0138)\end{array}$ & $\begin{array}{c}0.0089 \\
(0.0198)\end{array}$ \\
\hline Government spending & $\begin{array}{l}0.1401 * \star \\
(0.0679)\end{array}$ & $\begin{array}{l}0.1539 * * \\
(0.0691)\end{array}$ & $\begin{array}{l}0.1428 * * \\
(0.0671)\end{array}$ & $\begin{array}{c}0.1420 * \\
(0.0757)\end{array}$ \\
\hline Representative government & $\begin{array}{l}0.0354 * \star \star \\
(0.0123)\end{array}$ & $\begin{array}{l}0.0353 * \star \star \\
(0.0125)\end{array}$ & $\begin{array}{l}0.0309 * \star \star \\
(0.0126)\end{array}$ & $\begin{array}{c}0.0112 \\
(0.0124)\end{array}$ \\
\hline Crisis & $\begin{array}{c}0.3035^{\star} \\
(0.1782)\end{array}$ & $\begin{array}{c}0.3101^{*} \\
(0.1862)\end{array}$ & $\begin{array}{c}0.3355^{\star} \\
(0.2020)\end{array}$ & $\begin{array}{c}0.5262 * \\
(0.2722)\end{array}$ \\
\hline $\begin{array}{l}\mathrm{R}^{2} \\
\text { Arellano-Bond AR1/AR2 ( } \mathrm{p}- \\
\text { values) } \\
\text { Sargan test ( } \mathrm{p} \text {-value) } \\
\text { C. Lower- and lower-middle- } \\
\text { income countries }\end{array}$ & 0.128 & 0.124 & 0.129 & $\begin{array}{l}0.021 / 0.217 \\
0.305\end{array}$ \\
\hline Lagged Gini & & & & $\begin{array}{l}0.5408 * * * \\
(0.0920)\end{array}$ \\
\hline Financial markets development & $\begin{array}{l}0.0677 * \star \\
(0.0316)\end{array}$ & $\begin{array}{l}0.0646^{* *} \\
(0.0299)\end{array}$ & $\begin{array}{l}0.0744^{*} \\
(0.0370)\end{array}$ & $\begin{array}{l}0.0504^{* *} \\
(0.0225)\end{array}$ \\
\hline Growth of GDP per capita & $\begin{array}{l}-0.0614 \\
(0.0498)\end{array}$ & $\begin{array}{l}-0.0553 \\
(0.0493)\end{array}$ & $\begin{array}{l}-0.0571 \\
(0.0505)\end{array}$ & $\begin{array}{l}-0.0457 \\
(0.0541)\end{array}$ \\
\hline Inflation & $\begin{array}{c}0.0242 * \\
(0.0131)\end{array}$ & $\begin{array}{c}0.0249 * \\
(0.0129)\end{array}$ & $\begin{array}{c}0.0252 * \\
(0.0132)\end{array}$ & $\begin{array}{c}0.0105 \\
(0.0260)\end{array}$ \\
\hline Trade openness & $\begin{array}{l}-0.0052 \\
(0.0095)\end{array}$ & $\begin{array}{l}-0.0053 \\
(0.0095)\end{array}$ & $\begin{array}{l}-0.0062 \\
(0.0097)\end{array}$ & $\begin{array}{l}0.0209 * \star \\
(0.0089)\end{array}$ \\
\hline Government spending & $\begin{array}{l}0.1071^{\star *} \\
(0.0539)\end{array}$ & $\begin{array}{l}0.1099 * * \\
(0.0521)\end{array}$ & $\begin{array}{l}0.1131 * * \\
(0.0532)\end{array}$ & $\begin{array}{c}0.0448 \\
(0.0383)\end{array}$ \\
\hline Representative government & $\begin{array}{c}0.0002 \\
(0.0122)\end{array}$ & $\begin{array}{c}0.0002 \\
(0.0121)\end{array}$ & $\begin{array}{c}0.0024 \\
(0.0124)\end{array}$ & $\begin{array}{l}0.0357 * \star \\
(0.0152)\end{array}$ \\
\hline Crisis & $\begin{array}{c}0.4305^{\star} \\
(0.2284)\end{array}$ & $\begin{array}{c}0.4133 * \\
(0.2260)\end{array}$ & $\begin{array}{c}0.4026^{\star} \\
(0.2313)\end{array}$ & $\begin{array}{c}0.6742 * \\
(0.3757)\end{array}$ \\
\hline $\mathrm{R}^{2}$ & 0.115 & 0.104 & 0.110 & $0.014 / 0.420$ \\
\hline
\end{tabular}


Arellano-Bond AR1/AR2 (p0.630

values)

Sargan test (p-value)

Observations: panel A=234, panel $\mathrm{B}=196$, panel $\mathrm{C}=280$ obs. . IV=instrumental variables. GMM estimates are system. $* * *, * *$ and $*$ indicate statistical significance at the $1 \%$, 5\% and $10 \%$ levels, respectively. 